\title{
Enzymatic transesterification of palm stearin and olein blends to produce zero-trans margarine fat
}

\author{
Mohamed Sellami, Hanen Ghamgui, Fakher Frikha, Youssef Gargouri and Nabil Miled ${ }^{*}$
}

\begin{abstract}
Background: Food industries aim to replace trans fat in their products by formulations having equivalent functionality and economic viability. Enzymatic transesterification can be a technological option to produce trans free fats targeting commercial applications.

Results: Palm stearin and palm olein blends in different ratios were enzymatically transesterified in a solvent free system using a Rhizopus oryzae lipase immobilised onto $\mathrm{CaCO}_{3}$ to produce a suitable fat for margarine formulation. Slip melting points and triacylglycerols profiles were evaluated upon transesterification. Results indicated that all transesterified blends had lower slip melting points than their non transesterified counterparts. Furthermore, the triacylglycerols profile showed a decrease in the concentration of the high melting point triacylglycerols. The rheological analysis showed that margarine prepared with the transesterified blend showed a better spreadability than that of a control margarine prepared with non transesterified fat. Adding powder of dry bark orange to margarine preparation improved its colour and fairly affected its spreadability and rheological behaviour. The margarine prepared with transesterified fat displayed a rheological behaviour that was comparable to that of commercial sample.

Conclusions: This study is an ecofriendly approach to the utilization of relatively low value bioresources like palm stearin and palm olein for making margarine free of trans fatty acids that are now implicated as risk factor for heart diseases.
\end{abstract}

\section{Background}

Margarine was originally developed in 1869 as an alternative to butter which was in short supply and was also expensive [1]. Margarine is a water-in-oil emulsion. The aqueous phase consists of water, salt and preservatives. The fatty phase, which contributes to the polymorphic behaviour of margarine, is a blend of oils and fats, antioxidants and emulsifiers. Traditionally, the solid fat content of margarine is obtained by hydrogenation of liquid oils. Hydrogenation results in the formation of trans fatty acids where some cis double bonds are rearranged to trans bonds [2,3]. Several studies have suggested a direct relationship between trans fatty acids and increased risk for coronary heart diseases as well as raise of plasmatic lipid levels [3-7]. Different processes are currently available for the production of zero-trans solid fats in the food industry including chemical [8] or enzymatic

\footnotetext{
* Correspondence: nmiled@yahoo.com

Laboratoire de Biochimie et de Génie Enzymatique des Lipases, ENIS, Université de Sfax, route de Soukra, BPW 3038-1173 Sfax, Tunisia
}

transesterification [9,10]. Chemical transesterification usually needs cleaning process to remove the residual catalyst besides the formation of undesirable products. It is being successfully replaced by enzymatic processes of modifying fats and oils by utilizing lipases from various origins [11]. Enzymatic conversion of fats has been reported by various researchers [12-14]. Ghazali et al. [14] have conducted in hexane media the enzymatic transesterification of palm olein with nonspecific and 1,3-specific lipases immobilized on Celite. The effects of transesterification of palm olein by the various lipases resulted in changes in the triglycerides mixture and no clear correlation between the enzyme positional specificity and the products formed was found.

Palm oil is extracted from the fruit of oil palm, Elaeis guineensis. It is one of the traditional fats that have been widely used throughout the world in the human diet. Global palm oil production was estimated to 45.9 millions of tons during 2009-2010, accounting for $40 \%$ of the worldwide production of total dietary oils [15]. Palm 
oil contains a mixture of high and low melting points triacylglycerols. Using a simple dry fractionation process under controlled conditions, palm oil can be resolved into two fractions, namely olein (liquid fraction) and stearin (solid fraction) [16]. Palm olein is rich in low melting point triacylglycerols and is the mostly used fraction [8]. However, the high melting point fraction (palm stearin, melting point ranging from 45 to $55^{\circ} \mathrm{C}$ ) is hardly used in manufacturing edible fats due to its low plasticity [16]. Nevertheless, palm stearin deserves attention as a potential hard fat of vegetable origin to replace hydrogenated lipids. It might be appropriately blended and interesterified with liquid oils in order to modify the physical characteristics of the mixture to meet the functional properties and the quality required for margarine preparation.

Lai et al. [17] have used nonspecific and 1,3-specific lipases to transesterify mixtures of palm stearin and sunflower oil at a 40:60 mass ratio in a solvent-free medium. The authors have found that the palm stearin and sunflower oil mixtures were converted to a more fluid product. In the same context, Lai et al. [10] have also transesterified a mixture of palm stearin and palm kernel olein using the same lipases. They reported that the enzymatic transesterification was able to produce fat mixtures with substantially lower melting points by repositioning the fatty acids of triglycerides in the higher melting range to form lower-or middle-melting components.

In the same context, this work reports the synthesis of a fatty phase by transesterification of palm stearin and palm olein using an immobilized Rhizopus oryzae lipase as a biocatalyst. The maximal rate of palm stearin that is usually added to a standard table margarine formulation is $10 \%$ [16]. The purpose of this work was to maximise the palm stearin proportion in the fatty phase (higher than 35\%). A margarine was prepared out of the palm stearin/palm olein interesterified $(40 / 60 ; \mathrm{w} / \mathrm{w})$ mixture used as fatty phase. Slip melting point and rheological properties of the margarine were studied. In order to improve the colour, powder of dry bark orange was added to one margarine sample which rheological properties were studied.

\section{Methods}

\section{Production and immobilization of lipase}

Rhizopus oryzae lipase was produced as described by Ben Salah et al. [18]. The enzyme immobilization was made onto $\mathrm{CaCO}_{3}$ as described by Ghamgui et al. [19]. The activity of the immobilized lipase was measured titrimetrically with a $\mathrm{pH}$-stat, under the standard assay conditions described previously by Rathelot et al. [20] using olive oil (10\%) emulsion as substrate. One international unit (IU) of lipase activity was defined as the amount of lipase that catalyzes the liberation of $1 \mu \mathrm{mol}$ of fatty acid per minute at $\mathrm{pH} 8.5$ and $37^{\circ} \mathrm{C}$.

\section{Fractionation process}

Refined, bleached and deodorized palm oil, of iodine value 50, was obtained from the Tunisian Olive Oil Office. It was fractionated in the laboratory by a dry fractionation process, according to the method described by Thiagarajah [21]. RBD palm oil was melted and kept homogenized at $70^{\circ} \mathrm{C}$ to destroy all crystals present. The melted oil was stirred at $25 \mathrm{rpm}$ to keep it homogenized. The temperature was then decreased to $30^{\circ} \mathrm{C}$. After stabilization, two fractions were obtained, a solid fraction: palm stearin (PS) and a liquid fraction: palm olein (PO). They were separated by vacuum filtration.

\section{Enzymatic transesterification}

Transesterification reactions using various palm stearine/ palm olein (PS/PO) mixtures (35/65, 40/60 and 60/40; $\mathrm{w} / \mathrm{w})$ were conducted in screw-capped flasks containing $10 \mathrm{~g}$ of total lipids. Reactions were monitored for 72 hours at $50{ }^{\circ} \mathrm{C}$ using $1000 \mathrm{IU}$ of immobilized lipase and under stirring $(200 \mathrm{rpm})$. The biocatalyst was removed from reaction samples by centrifugation at $8000 \mathrm{rpm}$ for $5 \mathrm{~min}$, washed thoroughly with hexane and reused in the reusability study and the supernatant was used for determining the melting point or the triacylglycerols composition. A control experiment was carried out in the same conditions without adding the enzyme.

\section{Slip melting point (SMP)}

SMP was determined according to the AOCS Method Cc.3.25 [22]. Capillary tubes filled each with $1 \mathrm{~cm}$ high column of fat were chilled in a refrigerator at $4^{\circ} \mathrm{C}$ before being immersed in a beaker of cold distilled water. The water was stirred and heated and the temperature was recorded when the column of fat rises in the tube.

\section{lodine value by Wijs method (IV) and acid value (AV)}

The iodine value and the acid value were determined according to the AOCS Method Cd-25 and Cd 3a-63, respectively [22]. The reported values are means of three measurements.

\section{Triacylglycerols (TGs) profiles}

The TGs profiles of the transesterified and nontransesterified blends of PS:PO were analyzed using a reversed-phase high performance liquid chromatography (HPLC, Shimadzu SCL-6A) equipped with a refractive index detector and with two C18 reverse phase analytical Shim-Pack CLC-ODS (M) columns connected in series 
for a good separation (the first column $(15 \mathrm{~cm} \times 4.6 \mathrm{~mm})$ and the second $(25 \mathrm{~cm} \times 4.6 \mathrm{~mm})$. During analysis, the column was maintained at $45{ }^{\circ} \mathrm{C}$. The mobile phase was a mixture of acetone/ acetonitrile at a ratio of 70:30 (v/v) and at a flow rate of $1.5 \mathrm{~mL} / \mathrm{min}$. Identification of TGs was done by comparison of retention times with those of commercial TGs standards.

\section{Fatty acid analysis}

Samples were dissolved in $0.5 \mathrm{~mL}$ of hexane. Then, $0.2 \mathrm{~mL}$ of potassium hydroxide in methanol $(2 \mathrm{~N})$ was added for the fatty acid methylation process. The mixture was vortexed then centrifuged and the upper phase containing fatty acid methyl esters were analyzed by Gas Chromatography (GC). GC analyses were performed on a Shimadzu, GC 17 A chromatograph, equipped with a flame ionization detector and a capillary column $(50 \mathrm{~m} \times 0.32 \mathrm{~mm} \times 0.5 \mathrm{~mm}$, PERICHROM Sarl, France). The oven temperature was programmed as follows: the initial temperature $\left(100^{\circ} \mathrm{C}\right)$ was raised to $150^{\circ} \mathrm{C}$ at a rate of $30^{\circ} \mathrm{C} / \mathrm{min}$ and held at this temperature for $5 \mathrm{~min}$. The temperature was then increased to $190^{\circ} \mathrm{C}$ (at $10^{\circ} \mathrm{C} / \mathrm{min}$ ) and maintained for $14 \mathrm{~min}$ before being increased (at $5^{\circ} \mathrm{C} / \mathrm{min}$ ) to $255^{\circ} \mathrm{C}$ and held for $10 \mathrm{~min}$. The injector and detector temperatures were 255 and $270^{\circ} \mathrm{C}$, respectively. Nitrogen was the carrier gas with a flow rate of $1.13 \mathrm{~mL} / \mathrm{min}$. The identification of fatty acids was achieved by comparing retention times with those of authentic standards analysed under the same conditions. Peak areas were measured with an HP computing integrator. Results which are means of triplicates were expressed as $\mathrm{w} / \mathrm{w}$ percentage of total fatty acids [23].

\section{Margarine formulation and preparation}

Unless otherwise indicated, the composition of the prepared margarine was: $81 \%$ transesterified fat, $14.8 \%$ water, $1 \%$ hard boiled egg yolk used as emulsifier, $0.1 \%$ sugar, $0.1 \%$ salt and $3 \%$ butter. Hard boiled egg yolk and butter were dissolved in the heated oil phase $\left(50^{\circ} \mathrm{C}\right)$, and sugar and salt were dissolved in the water phase. An Overhead Stirrer (Bioblock equipped with propeller stirrer) was used to homogenize the margarine samples. Both phases were stirred and cooled rapidly in order to obtain small and uniform crystals [24]. Three margarine samples were prepared using the transesterified fat at a $\mathrm{PS} / \mathrm{PO}$ mass ratio of 40/60. One margarine sample contained no butter and $84 \%$ of fat. The second contained 3\% of butter. The third sample contained $3 \%$ of butter and $0.2 \%$ of a powder of dry bark orange. A control margarine sample was prepared using non transesterified PS/PO mixture at a ratio of 40/60, w/w. Commercial margarine containing hydrogenated fat was also studied. It was purchased from a local supermarket in Sfax, Tunisia.

\section{Rheological analysis}

For all margarine samples, viscosity was followed at $10^{\circ} \mathrm{C}$ with a Stress Tech Rheologica Rheometer (Rheologica Instruments $\mathrm{AB}$, Lund, Sweden) conducted with a steel cone-plate $(\mathrm{C} 40 / 4)$.

\section{Results and discussion}

\section{Fractionation of palm oil}

Dry fractionation process was applied to separate palm oil into two fractions, olein and stearin, without the addition of chemicals or solvents. The dry fractionation is based on differences in melting points of triacylglycerols [25-27], and is a thermomechanical separation process where the high and low melting triacylglycerols are separated by partial crystallization, followed by filtration [28].

Table 1 summarizes the physicochemical characteristics of palm oil and its fractions. During fractionation, triacylglycerols are redistributed into two phases. As fractionation proceeds, the more saturated triacylglycerols are gradually concentrated in the solid phase (stearin) and the more unsaturated one is left in the liquid phase (olein). Major saturated fatty acids were lauric (C12:0), myristic (C14:0), palmitic (C16:0) and stearic acids (C18:0) whereas major unsaturated fatty acids consisted of three major ones: oleic (C18:1), linoleic (C18:2), and linolenic (C18:3) acids.

Iodine value (IV) reflects the unsaturation level of fats and oils. Among oil palm fractions, palm olein had a higher IV and lower slip melting point as compared to stearin. This is in agreement with its higher content in unsaturated fatty acids.

\section{Changes in slip melting points during transesterification}

Transesterification is used to modify the properties of triacylglycerol mixtures. The fatty acid chains are redistributed within the triacylglycerol molecules resulting generally in a change in the melting characteristics of the product in comparison with the starting mixture [9].

In a preliminary study (data not shown), we have checked the transesterification performance of Staphylococcus xylosus and Rhizopus oryzae lipases produced in our laboratory $[18,29]$ and immobilized onto $\mathrm{CaCO}_{3}[19]$ and Chirazyme ${ }^{\circledR}$ L-9 a commercial immobilized lipase from Rhizomucor miehei. These enzymes were tested in the transesterification of a 50:50 PS/PO (w,w) mixture. Upon a reaction time of $24 \mathrm{~h}$ a significant shift in the SMP was obtained for the ROL- and Chirazyme -catalyzed reactions (from 44 to $40-41^{\circ} \mathrm{C}$ ). However, no change in SMP was observed for S. xylosus- lipase-catalyzed reaction. These results are presumably related to the specificity of the ROL toward long-chain triacylglycerols [19] as 
Table 1 Characteristics and fatty acids composition of palm fraction; SFA: saturated fatty acids; UFA: unsaturated fatty acids

\begin{tabular}{|c|c|c|c|c|c|c|c|c|c|c|c|c|}
\hline \multirow{2}{*}{$\frac{\text { Sample }}{\text { Palm fraction }}$} & \multicolumn{3}{|c|}{ Characteristics } & \multicolumn{9}{|c|}{ Fatty acids composition (\%) } \\
\hline & $\begin{array}{c}\text { Saponification } \\
\text { value }(\mathrm{mgKOH} / \mathrm{g})\end{array}$ & $\begin{array}{c}\text { Iodine value } \\
\left(\mathrm{gl}_{2} / 100 \mathrm{~g}\right)\end{array}$ & $\begin{array}{c}\text { Slip melting } \\
\text { point }\left({ }^{\circ} \mathrm{C}\right)\end{array}$ & C 12:0 & C $14: 0$ & C 16:0 & C 18:0 & C 18:1 & C 18:2 & C 18:3 & $\sum$ SFA & $\sum$ UFA \\
\hline Palm oil & 200 & 50 & 42 & 0.15 & 0.90 & 43.30 & 4.00 & 41.82 & 9.60 & 0.24 & 48.35 & 51.66 \\
\hline Palm stearin & 199 & 38 & 54 & 0.10 & 1.08 & 55.94 & 3.73 & 32.40 & 6.65 & 0.10 & 60.85 & 39.15 \\
\hline Palm olein & 201 & 56.4 & 28 & 0.10 & 0.45 & 41.38 & 4.34 & 43.28 & 10.25 & 0.20 & 46.27 & 53.73 \\
\hline
\end{tabular}

compared to S. xylosus lipase more active on short-chain triacylglycerols [29], since PS/PO mixture is rich in long chain fatty acids.

In addition, $\mathrm{CaCO}_{3}$ was used as a support to immobilize ROL by adsorption. The choice of this support was based on results reported by Ghamgui et al. [19] which have tested five supports (Silica gel 60, AmberliteIRC-50, Carboxy-methyl Sephadex, Celite 545 and $\mathrm{CaCO}_{3}$ ) to immobilize ROL by the adsorption technique. The authors have found that $\mathrm{CaCO}_{3}$ was the most suitable support to immobilize ROL since they have obtained a high yield of immobilization (93.75\%).

Moreover, the most widely used lipases in the synthesis reaction were commercial lipases which are usually microbial extracellular enzymes produced by fermentation of yeasts, fungi or bacteria. Unfortunately, the utilization of commercial enzymes to perform the transesterification is still very expensive. The use of low-cost lipases like Rhizopus oryzae lipase (ROL) may increase the process economical and environmental attractiveness. No previous studies involving ROL in the transesterification reaction to produce fat phase suitable for margarine preparation were reported.

The slip melting points (SMP) of three blends containing various palm stearin (PS)/ palm olein (PO) ratios (35/65, 40/60 and 60/40; w/w) decreased during transesterification time course (Figure 1). This is likely to be

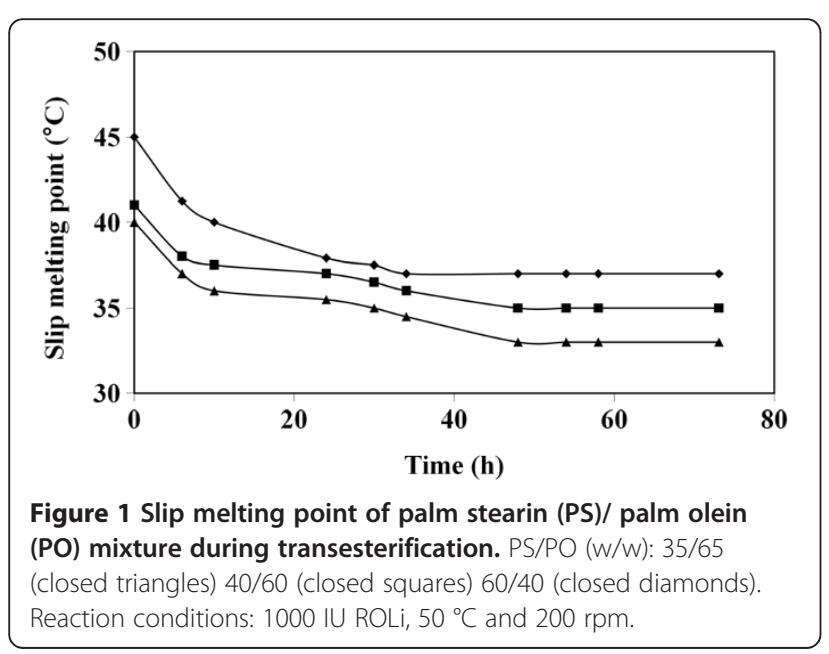

explained by the rearrangement of fatty acids within triacylglycerols (TGs) using ROL as a biocatalyst. No changes were observed in the SMP for control experiments carried out without enzyme. After $48 \mathrm{~h}$ of reaction time, the SMP remained constant. This might indicate that the reaction reached the equilibrium. These results are in agreement with the decrease in the SMP of palm stearin/palm kernel olein mixture after transesterification using Pseudomonas lipase [10]. The SMP increases as the amounts of PS augment in the starting blends (Figure 1), due to a greater content in highmelting triacylglycerols in PS.

SMP of PS/PO (40/60; w/w) decreased after 24 h of reaction time from $41{ }^{\circ} \mathrm{C}$ to $37^{\circ} \mathrm{C}$. This suggests a possible usage of this blend in the preparation of a table margarine for which a slip melting point around body temperature is required for a proper mouthfeel. Furthermore, stopping the reaction at $24 \mathrm{~h}$ would allow to reduce the reaction cost. This blend was subjected to further analysis in order to be used in margarine formulation.

To check the quality of the blend at the end of the reaction, the acid value was determined. It is defined by Woodlat [30] as the number of $\mathrm{mg}$ of $\mathrm{KOH}$ required to neutralize $1 \mathrm{~g}$ of fatty acids in an oil. As shown in Table 2, the acid value increased slightly from the starting blend (from 0.14 to $0.39 \mathrm{mg} \mathrm{KOH} / \mathrm{g}$ oil). Such value is still acceptable and there is no need to further refine the final product.

\section{Changes in triacylglycerol profiles during transesterification}

PS/PO (40/60; w/w) mixture was analyzed by HPLC to determine the triacylglycerols profile before (Figure $2 \mathrm{~A}$ ) and after $24 \mathrm{~h}$ of enzymatic transesterification (Figure 2B). Prior to transesterification, the blends contained higher proportions of high melting point triacylglycerols, such as POP (37\%), POS (4.24\%), and PPP (33\%). After transesterification, the amounts of these saturated TGs decreased and lower melting point TGs such as LOO (8\%), LnLnO (5.7\%), and OOO (12.02\%) were formed (Table 2). The changes in the triacylglycerols composition were due to the rearrangement of the fatty acids during interesterification. 
Table 2 Triacylglycerol composition (\%) and acid values (AV) (mg KOH/g oil) of palm stearin-palm olein blend (40:60, $\mathrm{w} / \mathrm{w}$ ) before and after $\mathbf{2 4} \mathrm{h}$ of transesterification by with $\mathrm{R}$. oryzae lipase (fatty acids: P, Palmitic acid; O, oleic acid; L, linoleic acid; Ln, Linolenic acid and S, stearic acid)

\begin{tabular}{lccccccccc}
\hline Sample & AV & \multicolumn{7}{c}{ Triacylglycerols } \\
\cline { 3 - 9 } & & LnLnO & LOO/LnOO & POL & OOO & POP/POO & PPP & SOO & POS \\
\hline Non transesterified blend & 0.14 & 1.2 & 5.56 & 2.11 & 8.46 & 37 & 33 & 1.33 & 4.24 \\
Transesterified blend & 0.39 & 5.7 & 8 & 2.3 & 12.02 & 30.1 & 26.79 & 1.1 & 5.33 \\
\hline
\end{tabular}

These results are in agreement with previous findings [31-34] that transesterification of fats and oil blends was often accompanied by changes in the SMP.

\section{Preparation of margarines and rheological analysis}

The PS/PO (40/60; w/w) blend transesterified with $1000 \mathrm{IU}$ of ROLi for $24 \mathrm{~h}$ of reaction time was used as a fatty phase to produce table margarine samples which were prepared in compliance with the margarine formulation recommendations [35]. Hard boiled egg yolk (1\%) was used as emulsifier. Egg yolk contains about $10 \%$ of phospholipids which are desirable emulsifiers widely used in food formulations [36]. Egg yolk was boiled in order to avoid any risk of product contamination. Figure 3 shows three margarine samples. The first was prepared with non transesterified blend (Figure 3A) and the two others were prepared with transesterified blend (Figure $3 \mathrm{~B}$ and $\mathrm{C}$ ). In order to give the product a butter-like attractive colour, powder of dry bark orange was added to the last margarine preparation (Figure $3 \mathrm{C}$ ). This powder used as a source of carotenes gave to the margarine sample a yelloworange colour, very close to that of butter. A patent describing this formulation has been filed with the patent office [37].
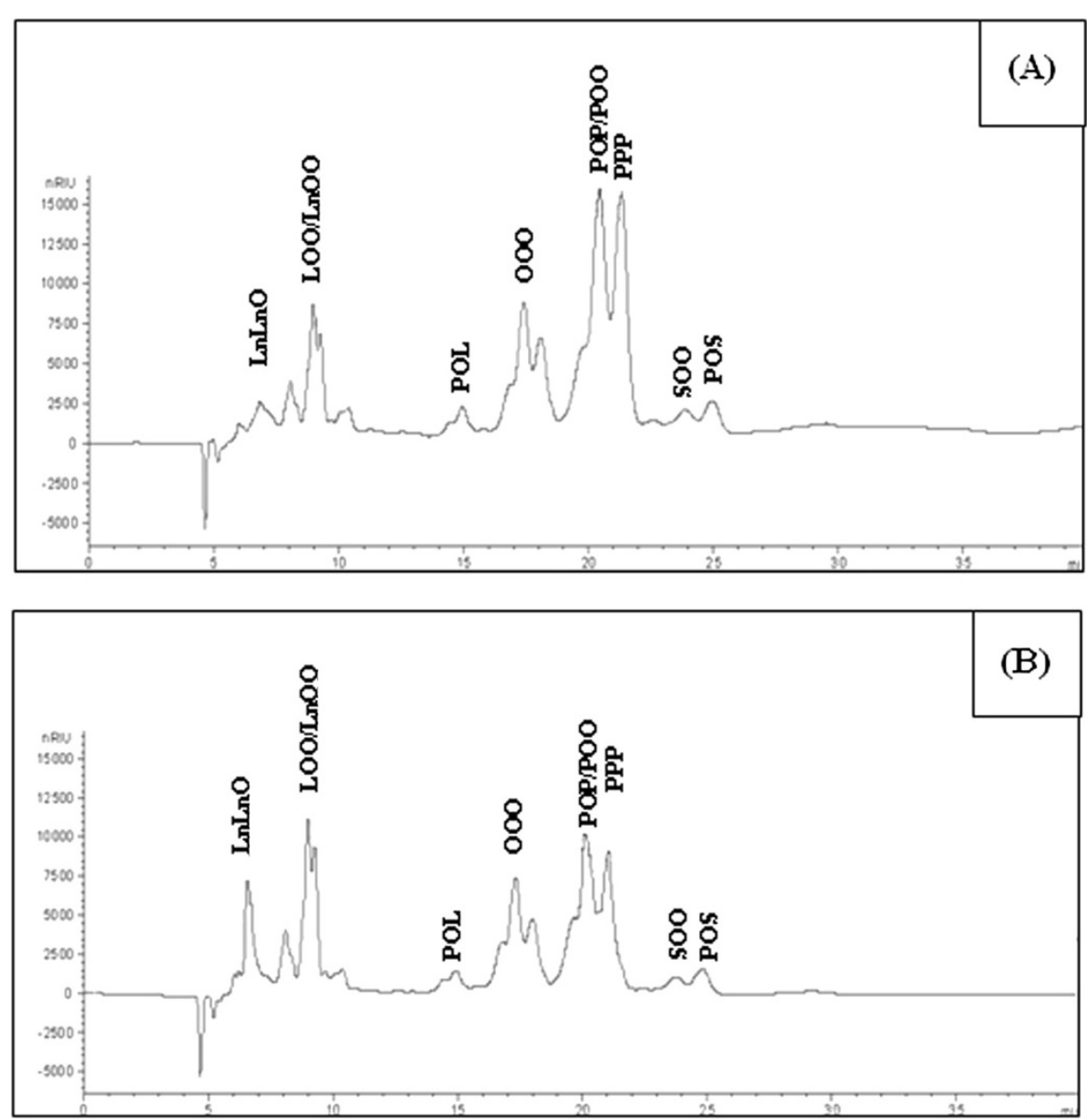

Figure 2 HPLC Chromatograms of (A) non-transesterified and (B) transesterified palm stearin and palm olein blend (40:60) obtained after $24 \mathrm{~h}$ of reaction time (P, Palmitic; O, oleic acid; L, linoleic; Ln, Linolenic acid; S, stearic acid). 


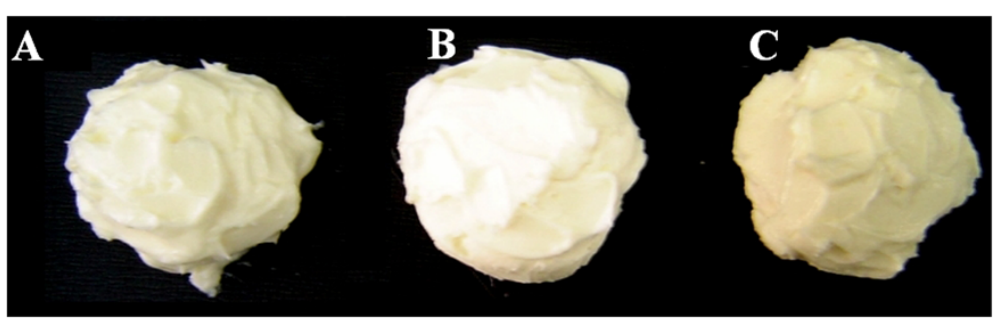

Figure 3 Margarine prepared with PS:PO (40:60) blend. (A) non transesterified blend, (B) transesterified blend, (C) transesterified blend containing powder of dry bark orange.

Figure 4A shows the variations of margarine apparent viscosity when increasing the shear strain rate. As expected, the viscosity declines strongly when shear strain rate increases for all studied margarines. They are characterized by a non-Newtonian rheological behaviour. Margarines prepared with transesterified fat blends showed a rheological behaviour comparable to that of the commercial one. Margarine prepared with the non transesterified blend displayed the greatest hardness since it exhibited the lowest variation of apparent viscosity when the shear strain rate increased from $50 \mathrm{~s}^{-1}$ to $200 \mathrm{~s}^{-1}$. This rheological behaviour is likely to be the consequence of the high slip melting point of the non transesterified blend.

Figure $4 \mathrm{~B}$ shows the variations of shear stress with increasing the shear strain rate. As the shear strain rate was increased, no significant deformation took place until the resulting stress reaches the shear yield stress
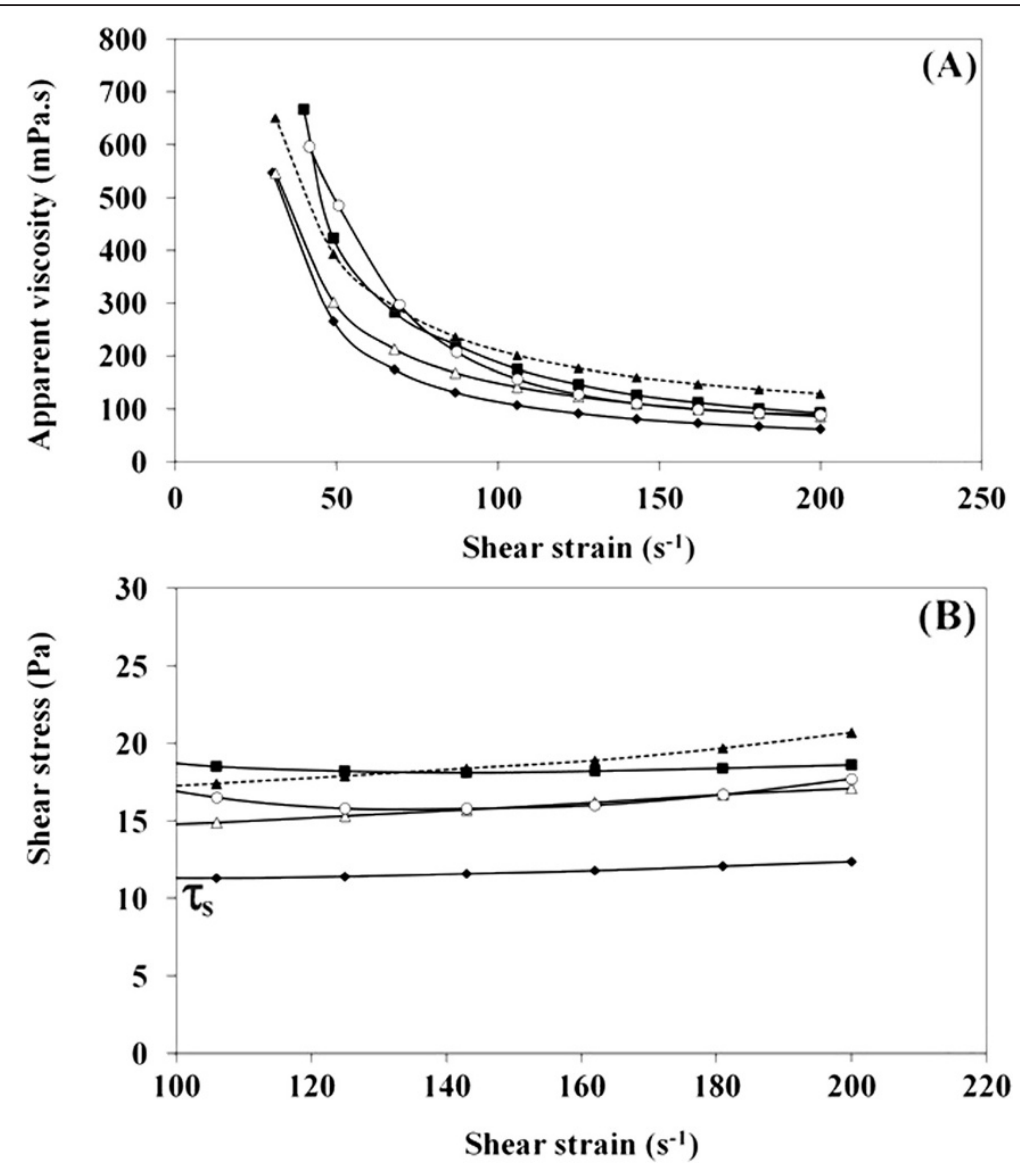

Figure 4 Rheological data, (A) Effect of shear strain rate on the apparent viscosity. (B) Effect of shear strain rate on the shear stress. Margarines prepared with PS:PO (40:60) blend. (closed diamonds) non transesterified blend added $3 \%$ butter; (closed squares) transesterified blend; (closed triangles) transesterified blend added $3 \%$ butter; (open triangles) transesterified blend added $3 \%$ butter and $0.2 \%$ powder of dry bark orange; (open circles) commercial margarine sample. 
value $\left(\tau_{\mathrm{s}}\right)$. The fat behaves like a rigid solid until the shear stress exceeds the limit value $\left(\tau_{s}\right)$, and the fat starts flowing like a Newtonian liquid. This curve is a characteristic of the plastic fat behaviour of margarine [38]. This behaviour is due to the presence of a fat crystal network [39]. Triacylglycerol crystals of margarine fatty phase are associated with each other by means of primary and secondary bonds [39], leading to a threedimensional structure that maintains the solid state.

Table margarine must be spreadable when taken straight from the refrigerator. That's why all rheological analysis were performed at $10^{\circ} \mathrm{C}$; temperature of refrigerator's butter compartment. $\tau_{\mathrm{s}}$ which represents also a measure of margarine spreadability was determined. Margarines prepared with transesterified fat had a better spreadability than those prepared with a non transesterified blend. Furthermore, the spreadability of transesterified fat margarine was similar to that of a commercial product. Since butter might be added to a margarine preparation at a maximal rate of 3\% [35], we checked that adding $3 \%$ of butter to the zero trans fat margarine did not affect its rheological behaviour. The rheological behaviour of the margarine prepared with powder of dry bark orange was fairly similar to the commercial product.

\section{Reusability of the biocatalyst}

One important factor limiting the use of lipase catalyzed reactions at an industrial scale is the high enzyme cost which can determine the economic viability of any biosynthetic process [40]. The cost efficiency of the reaction could be greatly improved by reusing the lipase for several reactions [41]. After $24 \mathrm{~h}$ of reaction time, the same immobilized enzyme was reused many times. After a reaction cycle, the immobilized lipase was separated from the reaction mixture by centrifugation, washed thoroughly with hexane and a fresh substrate sample was added to the same enzyme. No significant decrease in the enzyme activity was observed for 4 cycles of reuse and the residual activity was $90 \%$. Upon the fifth cycle, the enzyme lost $50 \%$ of its initial activity (Figure 5). The reason for the reduction of enzyme activity can be partly explained by desorption of lipase from the adsorbent or denaturation after many cycles of use. These results indicate the feasibility of enzyme recycling in this system. We used in a previous study [42] the same biocatalyst for 20 cycles in the synthesis of wax esters without significant loss of its activity. This difference between the two reactions could be explained by the composition of the reaction medium (solvent, water content, substrate chemistry) or the operating conditions.

\section{Conclusion}

This study has shown that enzymatic transesterification was an effective way to modify the physical and chemical

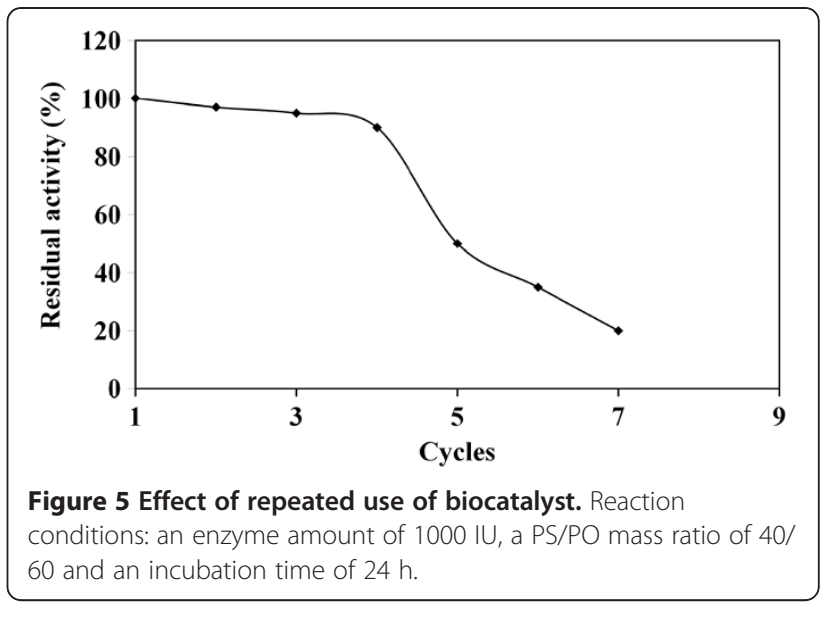

properties of palm stearin and palm olein blends. The enzymatic transesterification allows to obtain fats with optimum melting characteristics for use in margarine production. The rheological analysis showed that margarine prepared with the transesterified blend showed a better spreadability than that of a control margarine prepared with non transesterified fat. Adding powder of dry bark orange to margarine preparation improved its colour and fairly affected its spreadability and rheological behaviour.

\section{Competing interests}

The authors declare that they have no competing interests.

\section{Authors' contributions}

MS, HG and FF designed the experiments, carried out the synthesis and the analysis of margarine and drafted the manuscript.YG and NM have conceived research and approaches and have given final approval of the version to be published. All authors read and approved the final manuscript.

\section{Acknowledgments}

This work received financial support from "Ministère de l'enseignement supérieur et de la recherche scientifique, Tunisie" granted to the Laboratoire de Biochimie et de Génie Enzymatique des Lipases.

Received: 5 August 2011 Accepted: 2 August 2012

Published: 13 August 2012

\section{References}

1. Chrysam MM: Margarines and spreads. New York: John Wiley and Sons; 1996.

2. List GR, Emken EA, Kwolek WF, Simpson TD, Dutton HJ: Zero trans margarines: preparation, structure, and properties of interesterified soybean oil-soy trisaturate blends. J Am Oil Chem Soc 1977, 54:408-413.

3. Fomuso $L B$, Akoh CC: Enzymatic modification of high-laurate canola to produce margarine fat. J Agric Food Chem 2001, 49:4482-4487.

4. Mensink RP, Katan MB: Effect of dietary trans-fatty acids on high-density and low-density lipoprotein cholesterol levels in healthy subjects. N Engl J Med 1990, 23:439-445.

5. Zock PL, Katan MB: Hydrogenation alternatives: effects of trans-fatty acids and stearic acid versus linoleic acid on serum lipids and lipoproteins in humans. J Lipid Res 1992, 33:399-410.

6. Willett WC, Stampfer MJ, Manson JE, Colditz GA, Speizer FE, Ross MB, Sampson LA, Hennekens $\mathrm{CH}$ : Intake of trans-fatty acids and risk of coronary heart disease among women. Lancet 1993, 341:581-585. 
7. Micha R, Mozaffarian D: Trans fatty acids: effects on cardiometabolic health and implications for policy. Prostaglandins Leukot Essent Fatty Acids 2008, 79:147-152.

8. Norizzah AR, Chong CL, Cheow CS, Zaliha O: Effects of chemical interesterification on physicochemical properties of palm stearin and palm kernel olein blends. Food Chem 2004, 86:229-235.

9. Berben PH, Groen C, Christensen MW, Holm HC: Interesterification with immobilized enzymes. Society of Chemical Industry 2000, 121:1-2

10. Lai MO, Ghazali HM, Let CC: Effect of enzymatic transesterification on the fluidity of palm stearin-palm kernel olein mixtures. Food Chem 1998, 63:155-159.

11. Reshma MV, Saritha SS, Balachandran C, Arumughan C: Lipase catalyzed interesterification of palm stearin and rice bran oil blends for preparation of zero trans shortening with bioactive phytochemicals. Bioresour Technol 2008, 99:5011-5019.

12. Husum TL, Pederson LS, Nielson PM, Christensen MW, Kristensen D, Holm HC: Enzymatic interesterification: process advantages and product benefits. Palm Oil Development 2004, 39:7-10.

13. Ronne TH, Yang T, Mu H, Jacobsen C, Xu X: Enzymatic interesterification of butter fat with rapeseed oil in a continuous packed bed reactor. J Agric Food Chem 2005, 53:5617-5624.

14. Ghazali HM, Hamidah S, Che Man YB: Enzymatic transesterification of palm olein with nonspecific and 1,3-Specific lipases. J Am Oil Chem Soc 1995, 72(6):633-639.

15. FAOSTAT: Online Statistical Service; 2012. http://faostat.fao.org.

16. Lai OM, Ghazali HM, Cho F, Chong CL: Physical and textural properties of an experimental table margarine prepared from lipase-catalysed transesterified palm stearin:palm kernel olein mixture during storage. Food Chem 2000, 71:173-179.

17. Lai OM, Ghazali HM, Chong CL: Use of enzymatic transesterified palm stearin-sunflower oil blends in the preparation of table margarine formulation. Food Chem 1999, 64:83-88.

18. Ben Salah A, Fendri K, Gargouri Y: La lipase de Rhizopus oryzae: production, purification et caractéristiques biochimiques. Revue Française des Corps Gras 1994, 4:133-137.

19. Ghamgui H, Karra-Châabouni M, Gargouri Y: 1-Butyl oleate synthesis by immobilised lipase from Rhizopus oryzae: a comparative study between n-hexane and solvent-free system. Enzyme Microb Technol 2004, 35:355-363.

20. Rathelot J, Julien R, Canioni P, Coereli C, Sarda L: Studies on the effect of bile salt and colipase on enzymatic lipolysis. Improved method for the determination of pancreatic lipase and colipase. Biochimie 1975, 57:1117-1122

21. Thiagarajah T: Refining of palm and palm kernel oils. Malaysia: Selected readings on palm oil for participants of palm oil familiarization programme. PORIM. Ministry of Primary Industries; 1992.

22. AOCS: Official and tentative methods of the American Oil Chemists' Society Champaign. Champaign. IL: AOCS Press; 1990.

23. Sagdiç O, Donmez M, Demirci M: Comparison of characteristics and fatty acid profiles of traditional Turkish yayik butters produced from goats, ewes or cows milk. Food Control 2004, 15:485-490.

24. Che Man YB, Swe PZ: Thermal analysis of failed batch palm oil by differential scanning calorimetry. J Am Oil Chem Soc 1995, 72:1529-1532.

25. Ng WL: Nucleation from palm oil melt; PORIM. Malaysia: Ministry of Primary Industries; 1989

26. Siew WL, Ng WL: Diglycerides content and composition as indicators of palm oil quality. J Sci Food Agric 1995, 69:73-79.

27. Siew WL, Ng WL: Effect of diglycerides on the crystallization of palm olein. J Sci Food Agric 1996, 71:496-500

28. Kellens M: New developments in the fractionation of palm oil; PORIM. Malaysia: Ministry of Primary Industries; 1993.

29. Mosbah H, Sayari A, Verger R, Gargouri Y: Gly311 residue triggers the enantioselectivity of Staphylococcus xylosus lipase: a monolayer study. J Colloid Interface Sci 2007, 310:196-204.

30. Woodlat EE: The manufacture of soap, other detergents and glycerine. 2nd edition. England: Ellis Harwood Pub; 1985.

31. Forssell $P$, Kervinen $P$, Lappi M, Linko P, Suortti T, Poutanen K: Effect of enzymatic interesterification on the melting point of tallow-rapeseed oil (LEAR) mixture. J Am Oil Chem Soc 1992, 69:126-129.

32. Foglia TA, Petruso K, Feairheller SH: Enzymatic interesterification of tallow-sunflower oil mixtures. J Am Oil Chem Soc 1993, 70:281-285.
33. Ghazali HM, Maisarah A, Yusoff S, Yusoff MSAM: Triglyceride profiles and melting properties of lipase catalysed transesterified palm stearin and coconut oil. Asia Pac J Mol Biol Biotechnol. 1995, 3:280-289.

34. Zainal Z, Yusoff MSAM: Enzymatic Interesterification of palm stearin and palm kernel olein. J Am Oil Chem Soc 1999, 76:1003-1008.

35. Codex alimentarius: Codex standard for margarine. Codex Stan 321981 2001, 8:1-4

36. Luz EP, Tong W: Egg-yolk lipid fractionation and lecithin characterization. J Am Oil Chem Soc 2005, 82:571-578.

37. Sellami M, Ghamgui H, Frikha F, Gargouri Y, Miled N: Production de margarine végétale dépourvue d'acides gras trans.INNORPI. Tunisian patent filing number 2010-0311. 2010.

38. Segura JA, Herrera ML, Anon MC: Margarines: a rheological study. J Am Oil Chem Soc 1995, 72:375-378.

39. Haighton AJ: Work softening of margarine and shortening. J Am Oil Chem Soc 1965, 42:27-30.

40. Krishna SH, Sattur AP, Karanth NG: Lipase-catalyzed synthesis of isoamyl isobutyrate optimization using central composite rotatable design. Process Biochem 2001, 37:9-16.

41. Compton DL, Laszlo JA, Berhow MA: Lipase-catalyzed synthesis of ferulate esters. J Am Oil Chem Soc 2000, 77:513-519.

42. Aissa I, Sellami M, Kamoun A, Gargouri Y, Miled N: Optimization of immobilized lipase-catalyzed synthesis of wax esters by response surface methodology. Curr Chem Biol 2012, 6:77-85.

doi:10.1186/1472-6750-12-48

Cite this article as: Sellami et al.: Enzymatic transesterification of palm stearin and olein blends to produce zero-trans margarine fat. $B M C$ Biotechnology 2012 12:48.

\section{Submit your next manuscript to BioMed Central and take full advantage of:}

- Convenient online submission

- Thorough peer review

- No space constraints or color figure charges

- Immediate publication on acceptance

- Inclusion in PubMed, CAS, Scopus and Google Scholar

- Research which is freely available for redistribution 